\title{
The evolution of the Triassic-Jurassic Maliac oceanic lithosphere: insights from the supra-ophiolitic series of Othris (continental Greece)
}

\author{
JACKY FERRIÈRE ${ }^{1}$, FRANK CHANIER ${ }^{1}$, PETER O. BAUMGARTNER ${ }^{2}$, PAULIAN DUMITRICA ${ }^{2}$, \\ MARTIAL CARIDROIT ${ }^{1}$, VIVIANE BOUT-ROUMAZEILLES ${ }^{1}$, FABIEN GRAVELEAU ${ }^{1}$, \\ TANIEL DANELIAN $^{1}$ and SANDRA VENTALON ${ }^{1}$
}

\begin{abstract}
Keywords. - Téthys, Hellenides, Maliac ocean, Ophiolites, Sedimentary series, Radiolaria.
Abstract. - Major ophiolitic thrust sheets are widespread within the internal Hellenides, particularly in the Pelagonian domain (Greece and Albania). The ophiolitic sheets are notably well exposed in western Othris mountains of continental Greece. In that area, the structural stacking of oceanic nappes obducted in the Jurassic is particularly well constrained. New sedimentological and structural data from recently studied outcrops, together with new micropaleontological data, allow to reconsider the architecture of the ophiolitic nappes and their evolution in the Othris mountains. Our new data set includes notably the description of a Mid-Late Jurassic sedimentary succession, from basal litharenites and radiolarites to syn-obduction mélange, on top of the uppermost Mega Isoma ophiolitic Unit. These results are crucial in the perspective of constraining the Jurassic contractional evolution of the Maliac Ocean from the beginning of the subduction and intra-oceanic obduction to the final obduction on the Pelagonian continental crust. Another major result concerns the dating of primary conformable series of Middle and Late Triassic age on top of the pillow-lavas of the Fourka unit. Since this lava unit, with MORB affinities, is one of the syn-obduction Jurassic nappes, we propose that this very large Fourka nappe represents the major reference unit of the initial (Triassic) Maliac oceanic crust.
\end{abstract}

\section{Evolution de la lithosphère océanique maliaque triasico-jurassique : Apports de l'étude des séries supra-ophiolitiques d'Othrys (Grèce continentale)}

\begin{abstract}
Mots-clés. - Téthys, Hellenides, Océan Maliaque, Ophiolites, Séries sédimentaires, Radiolaires.
Résumé. - Des nappes ophiolitiques importantes caractérisent les Hellénides internes, notamment le domaine Pélagonien en Grèce et en Albanie. C'est le cas dans les montagnes d'Othrys, en Grèce continentale, où l'empilement des nappes ophiolitiques obduites au Jurassique est particulièrement bien contraint. Des données sédimentologiques et structurales acquises à la faveur de nouveaux affleurements, sur les principales nappes ophiolitiques d'Othrys occidentale, couplées à de nouvelles déterminations de microfossiles, permettent de préciser la nature et la mise en place de ces nappes. Nous décrivons notamment, pour la première fois, une série du Jurassique moyen-supérieur constituant la couverture sédimentaire océanique de l'importante unité ophiolitique de Méga Isoma. Cette série, constituée de litharénites et de radiolarites à la base, se termine par une formation syn-obduction de type mélange à blocs. Ces résultats s'avèrent être déterminants s'agissant de mieux contraindre les processus océaniques syn-convergence d'âge jurassique au sein de l'océan Maliaque entre le début de la subduction et de l'obduction intra-océanique jusque l'obduction finale sur la croûte continentale Pélagonienne. Un autre résultat majeur est l'obtention exclusive de datations du Trias moyen et supérieur sur les séries radiolaritiques reposant en contact stratigraphique indubitable sur les pillow-lavas de l'unité de Fourka. Cette unité triasique étant riche en laves de type MORB et présente au coeur de l'empilement jurassique de nappes syn-obduction, nous proposons de faire de cette unité de Fourka l'unité de référence de la croûte océanique initiale (triasique) de l'océan Maliaque.
\end{abstract}

\section{INTRODUCTION}

The internal Hellenides are characterized by the occurrence of numerous large ophiolitic sheets thrust during the Middle to Late Jurassic times (fig 1). These ophiolites are known along two main axes: an eastern one outcropping more or less in the Vardar domain and a western axis in the
Pelagonian zone (Supra-Pelagonian Ophiolites: SPO). The latter ophiolites are also thrust over the external units, notably over the Pindos zone. Some ophiolitic bodies, such as the Vourinos range, exist also between these two axes. The main ophiolitic sheets are those of the western axis. The ophiolites from Greece and Albania have been assigned to one or two different oceanic basins, the "Pindos-Mirdita"

1. UMR CNRS 8187 (LOG), University of Lille, UFR Sciences de la Terre, 59650 Villeneuve d'Ascq cedex, France.

2. Institute of Earth Sciences, Lausanne University, Géopolis, Room 3634, CH-1015 Lausanne, Switzerland

Corresponding author: frank.chanier@univ-lille1.fr

Manuscript received on October 15, 2014; accepted on March 7, 2015 
ocean on the western edge of the Pelagonian zone and/or the Maliac-Meliata-Vardar ocean on the eastern side of this zone (see recent discussions in Ferrière et al. [2012]; Robertson [2012]; Bortolotti et al. [2013]).

The SPO have been considered as obducted on the Pelagonian realm from the west [Dercourt, 1970; Hynes et al., 1972; Robertson et al., 1991; Saccani et al., 2003] or, in our opinion, from the Triassic-Jurassic Maliac ocean located on the east of the Pelagonian zone [Bernoulli and Laubscher, 1972; Ferrière, 1982, 1985; Baumgartner, 1985; Stampfli and Borel, 2002; Bortolotti et al., 2004, 2013; Schmid et al., 2008; Ferrière et al., 2012]. Many authors have proposed geochemical analyses of the SPO which are peridotite-rich units. Mafic rocks are less abundant and preor syn-obduction supra-ophiolitic sedimentary series, proven to be in stratigraphic contact above the ophiolitic magmatic rocks, are rare.

In the northern Hellenides, the lavas of the eastern SPO (e.g.: Vourinos) have a clear SSZ (Supra subduction zone) geochemical signature (e.g. low-Ti basalts), those from western areas (e.g. N-Pindos) show a larger variety from MORB to SSZ types [e.g. Capedri et al., 1981; Beccaluva et al., 1984; Jones and Robertson, 1991; Saccani et al., 2004; Saccani and Photiades, 2004]. Their ultramafic basements are also different: the Vourinos basement consists of harzburgites [Brunn, 1956; Zimmerman, 1972; Rassios and Moores, 2006], while the N-Pindos unit shows harzburgites and lherzolites [Capedri et al., 1980; Jones and Robertson, 1991; Ross and Zimmermann, 1996; Saccani and Photiades, 2004; Rassios and Moores, 2006]. Some Triassic and/or Jurassic mafic lavas are not linked to an ultramafic basement. They appear as scattered outcrops within small tectonic slices or as blocks inside mélange formations [Ferrière et al., 1988; Jones and Robertson, 1994; Danelian and Robertson, 2001; Saccani et al., 2003, 2011; Saccani and Photiades, 2004]. Due to the presence of lavas that are not coming from oceanic lithosphere, as the Triassic lavas linked to the rifting in the series of the Maliac ocean margins [see Ferrière, 1982], it is necessary to decipher the primary nature of such scattered exposures.

Pre- or syn-obduction supra-ophiolitic sedimentary series are uncommon, generally not well developed (a few meters of radiolarites) and often separated from their magmatic basement [Celet et al., 1980; Baumgartner, 1985; Jones and Robertson, 1991; Jones et al., 1992; Bortolotti et al., 2004; Chiari et al., 2012a]. Moreover most of the age determinations were performed on radiolarites covering pillow-lavas from large blocks or small slivers. The origin of these lavas are therefore generally unclear (e.g. lavas linked to rifting or blocks in mélanges). Two sets of ages have been observed in the Hellenides, in such sedimentary series: i) Middle Jurassic ages, particularly in the main ophiolitic units as Vourinos mountains [Chiari et al., 2003], N-Pindos area [Jones and Robertson, 1994], Argolis [Baumgartner, 1985] and Evia [Scherreiks et al., 2010] and, ii) Triassic ages generally concerning small units made up of pillow-lavas showing MORB or within plate basalts (WPB) affinities, in N-Pindos [Jones and Robertson, 1992], Peloponnessos [Danelian et al., 2000], Argolis [Bortolotti et al., 2001], Othris [Bortolotti et al., 2008], Evia [Scherreiks et al., 2010] and Koziakas mountains [Chiari et al., 2012a].
Triassic and Jurassic supra-ophiolitic series are well-exposed at new outcrops in Othris. Some of them show primary contact with the mafic ophiolitic rocks. In this article we focus on these sedimentary series. Our new data set allows to significantly constrain the age of two of the main ophiolitic units and the evolution of the Maliac oceanic lithosphere from its Triassic birth to its Jurassic obduction over the Pelagonian basement.

\section{GEOLOGICAL SETTING: THE OPHIOLITIC UNITS OF OTHRIS}

The West-Othris ophiolites of this study belong to the main ophiolitic units of the Hellenic western axis (SPO) (fig. 1). They belong to a set of syn-obduction nappes with weak Tertiary tectonic overprints, they can therefore be used as references for the Jurassic obduction processes [Ferrière, 1982]. The structural syn-obduction system, well-known since the 1970-1980 years [Ferrière, 1972, 1974, 1976, 1982, 1985; Hynes et al., 1972; Smith et al., 1975], is composed of sedimentary and magmatic nappes emplaced in Middle Jurassic times (figs 2 and 3). The lower syn-obduction tectonic units come from the Pelagonian platform (two units) and from the Maliac oceanic margin (five tectonic units overthrusting the Pelagonian ones) (for details see figs 2 and 3). All the sedimentary units especially those coming from the distal Maliac margin (Loggitsion units) show thick Triassic lavas linked to the rifting events.

The upper syn-obduction nappes are the ophiolitic units s.s. [Ferrière, 1982] (figs 3 and 4): i) the uppermost unit known as the Mega Isoma unit (MI) is made of thick ultramafic (harzburgites and lherzolites) and gabbroic formations, including few basic dykes and lavas. The distribution of the different types of peridotites in this unit is complex [Celet et al., 1980; Ferrière, 1982, 1985; Photiades et al., 2003; Barth et al., 2003, 2008]; ii) the Metalleion unit just below the MI sheet is a large harzburgitic unit tectonically covered by a mafic unit (dykes and few lavas); iii) the lowermost magmatic unit, known as the Fourka unit, is mostly composed of green-brown pillow-lavas, that outcrop on large surfaces [Celet et al., 1980; Ferrière, 1982].

In this article we focus on significant new outcrops of the well-developped, undisputable supra-ophiolitic sedimentary covers of the Fourka (Triassic series) and Mega Isoma (Middle Jurassic series) units.

\section{THE SERIES ASSOCIATED TO THE PILLOW-LAVAS OF THE FOURKA UNIT: THE MALIAC TRIASSIC OCEANIC CRUST}

The Fourka pillow-lavas unit, locally 300-400 m thick, defined some decades ago [Celet et al., 1980; Ferrière, 1982] is exposed on a very large surface in western and central Othris (about $35 \times 35 \mathrm{~km}$ ) (figs 1 and 2). The pillow-lavas are for most of them of MORB type, especially N-MORB and/or WPB affinities [Hynes, 1974; Ferrière, 1982; Bortolotti et al., 2008; Barth et al., 2009]. A Triassic age concerning siliceous beds with a primary contact on the Fourka lavas have been published by Bortolotti et al. [2008]. 


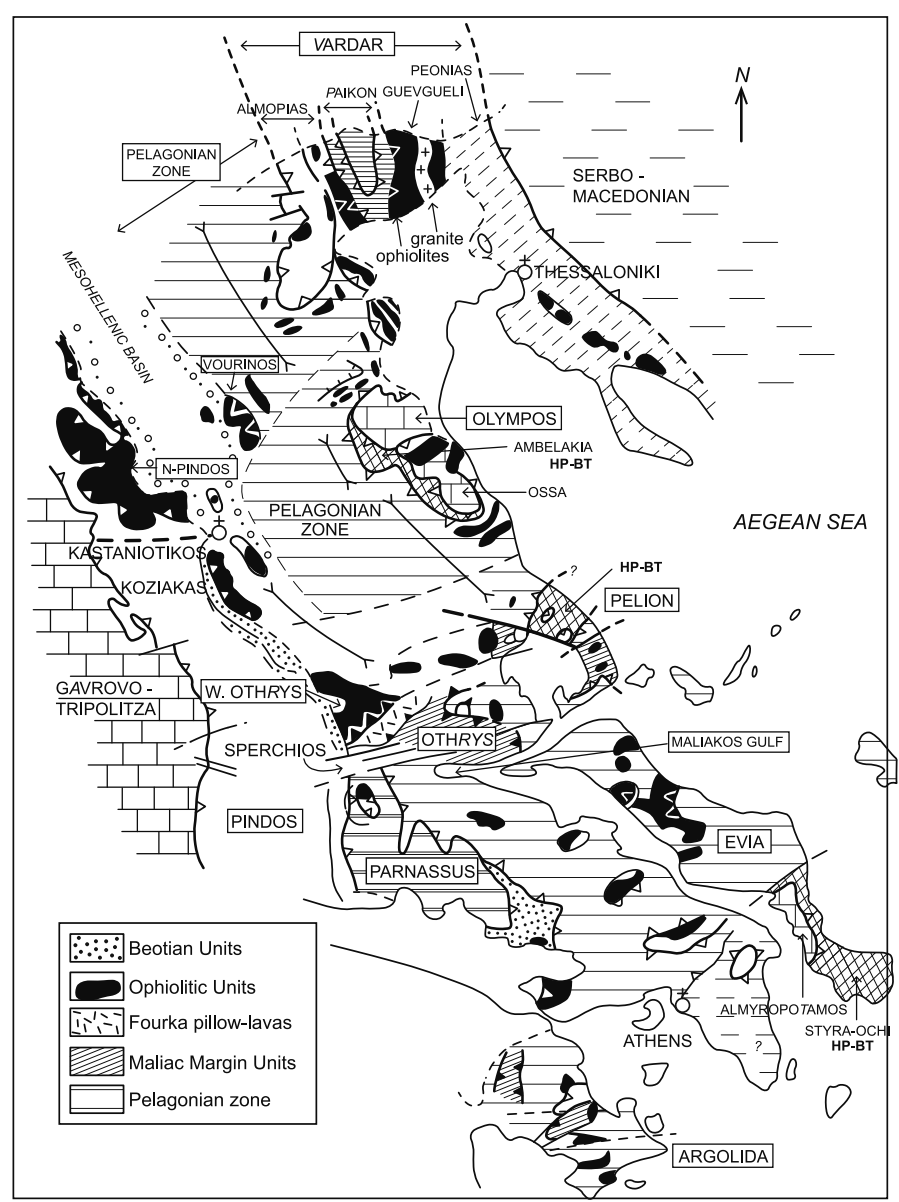

FIG. 1. - Main Maliac oceanic units in the Hellenides. Black: ophiolitic units with mafic and ultramafic rocks; dashed lines in Othris: Triassic ophiolitic pillow lavas (Fourka unit); oblique lines: Maliac margin sedimentary units. Abr: W-Othris: Western Othris; HP-BT: blueschists units. Pelagonian and Vardar zones = Internal zones

\section{Examples of Middle and Late Triassic radiolarites deposited on the Fourka pillow-lavas}

Along the Lamia-Domokos road, radiolarites and shales exist within and above pillow-lavas of the Fourka unit (figs 2 and 3 ). The outcrop located on the road to Kalamakion, $1.5 \mathrm{~km}$ west of the Fourka pass, is the most interesting as the basal contact of the sediments above the pillow-lavas is an undisputable primary stratigraphic contact (fig. 4 CC', fig. 5A and pl. IA). The $1.5 \mathrm{~m}$-thick red shales directly deposited on the lavas pass upward to red dm-thick bedded radiolarites. The radiolarian assemblages (samples YO 98 and 100, fig. 5A and pl. II) reveal latest Anisian-?earliest Ladinian ages with the following Radiolaria (ranges partly from Stockar et al. [2012]): Eptingium manfredi DUMITRICA (latest Anisian-?earliest Ladinian), Spongostephanidium spongosium DUMITRICA, Triassocampe scalaris DUMITRICA, KozUr \& Mostler, Pseudostylosphaera compacta (NAKASEKO \& NiSHIMURA), Pseudostylosphaera? sp. East of Moschokarya (fig. 4) red radiolarian beds interbedded between lava flows of the Fourka unit show an early Norian age (fig 5B, pl. IB and pl. II). Among Radiolaria, the following species have been found (sample FC 02): Xiphosphaera? fistulata CARTER (early-mid Norian),
Capnodoce sarisa DE WEVER (latest Carnian-early Norian), Capnodoce anapetes (latest Carnian-middle Norian), Kahlerosphaera norica KOZUR \& MocK (latest Carnianearly Norian), Pachus multinodosus TEKIN (late Carnianearly Norian), Sarla hadrecaena DE WEVER (collaboration with Y. Gingins and O. Schauner).

\section{A Triassic to Jurassic series on the Fourka pillow-lavas}

North of Moschokarya on the road to Xinias plain (figs 2 and 4) a well-exposed outcrop (about $300 \mathrm{~m}$ long) shows brown Fourka pillow-lavas and red shaly radiolarites overlain by purple sediments and lavas (fig 5C). Contacts between radiolarites and lavas are clearly stratigraphic contacts (pl. IC). At the base of the main outcrop, the red radiolarites contain radiolarian fossils and conodonts of Triassic age (F10-As 1 to 11, fig 5C and pl. II). A sample (As 2) near the base of the outcrop is attributed to late Illyrian (latest Anisian)-earliest Ladinian (ranges partly from Stockar et al. [2012]) with Cryptostephanidium sp.; Baumgartneria bifurcata DUMITRICA; Paroertlispongus multispinosus KOZUR \& MOSTlER (latest Anisian-?earliest Ladinian); probable Sepsagon? robustus LAHM. Two meters only above As 2, a sample (As 8) gives an Early Norian age with Betraccium sp.; Palaeosaturnalis triassicus (KOZUR \& MOSTLER); Renzium tricarinatum TEKIN, Capnodoce anapetes DEWEVER, Kahlerosphaera kemerensis kemerensis TEKIN.

At the top of the outcrop (F12-11 and 12, fig 5C), above siliceous folded red shales, a metric-thick outcrop of radiolarites gives a Jurassic age, especially early to late Bajocian (UAZ 3-4 for F12-12) with Yaocapsa (?) kisoensis YAO and late Bajocian-early Bathonian (UAZ 4-5 for F12-11b) with Striatojaponocapsa synconexa O'DOGHERTY, GORICAN and DUMITRICA.

Other small outcrops deposited on top of Fourka lavas have been studied. Those that could be dated are always Triassic in age (e.g. just north of Trilofon village the radiolarites contain Triassic conodonts, figs 4 and 5D).

\section{Clay analyses}

The clay mineral assemblages were determined on five samples from the Fourka series: two samples from the basal pelites of the Kalamakion section (F11-96 and F11-97, fig 5A); two samples from the Fourka Pass lavas (F11-02 and F11-87) and one sample from the Trilofon section (fig 3 and F11-128, fig 5D). Smectite -namely saponite- is the main component (45-88\% of the clay mineral fraction) of samples F11-02, F11-87 and F11-96, in association with corrensite $(21-50 \%)$, which is a regular interstratification of chlorite and smectite. The saponite is commonly produced through low-temperature $\left(20-80^{\circ} \mathrm{C}\right)$ alteration of basalts while corrensite points out slightly higher temperatures $\left(80-300^{\circ} \mathrm{C}\right)$. This specific clay mineral association suggests a provenance from the underlying lavas. The higher amount of illite in the oldest sample (F11-97) could be linked to the vicinity of the oceanic crust with the continental Pelagonian domain at this time.

\section{Interpretation of the Triassic Fourka series and pillow-lavas: the first Maliac oceanic crust}

Because of its lithologic characteristics (mafic pillow-lavas) and its structural location above the units coming from the 


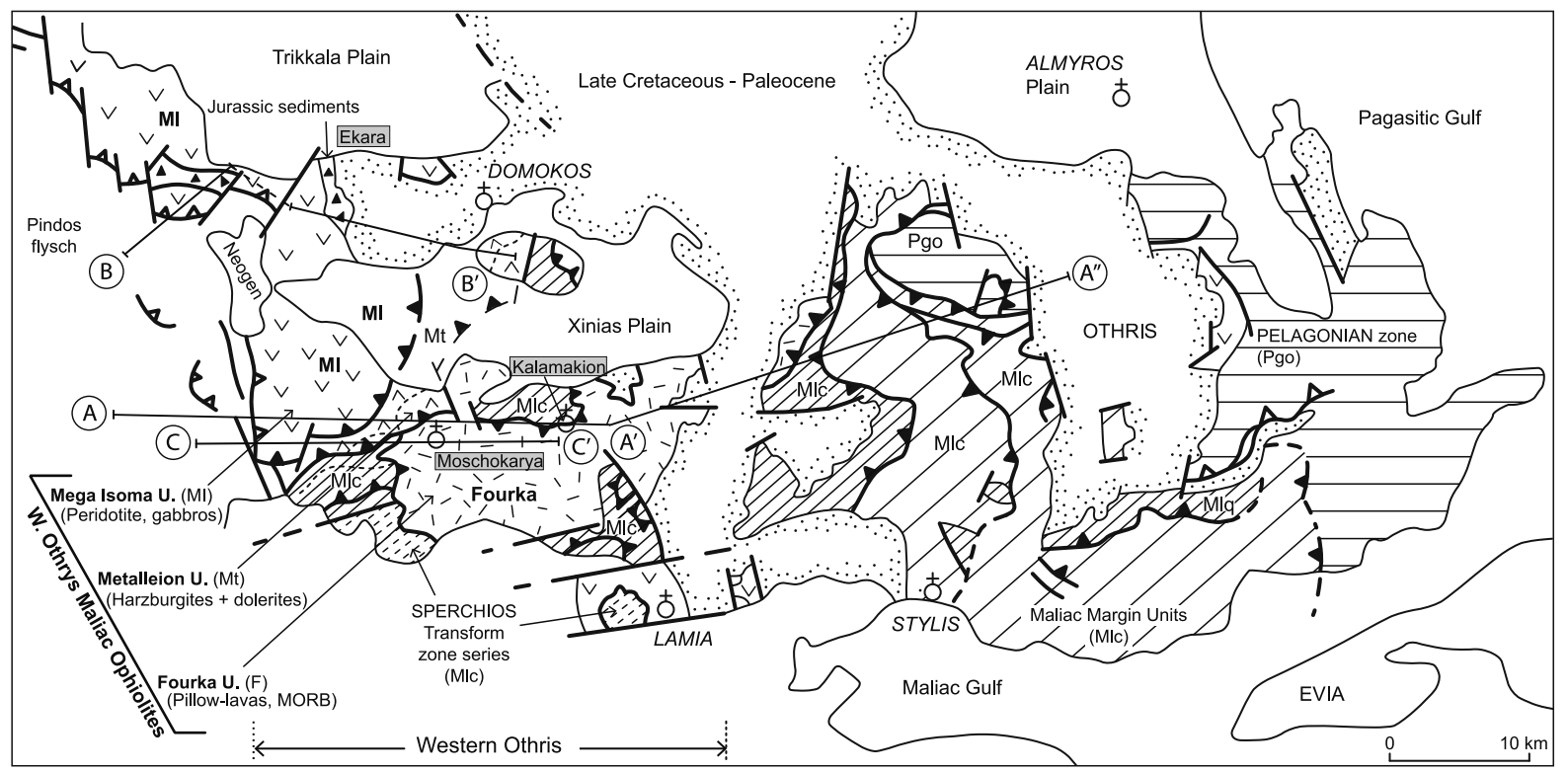

FIG. 2. - Schematic geological map of Othris [modified from Ferrière, 1982].

AA'A": cross-section figure 3; BB' and CC': cross-sections figure 4. Abr. Mlc: Maliac margin series; distal (closed oblique lines) and proximal (spaced oblique lines) sedimentary units.

distal Maliac margin (Loggitsion units) and beneath the ultramafic ophiolitic nappes (figs 2 and 3), the Fourka unit can be considered as the distal part of a volcanic passive margin or to an ophiolitic unit corresponding to a real oceanic crust. The volcanic passive margins are mainly identified by seismic studies in the ocean (eg. Seaward Dipping Reflectors) but some data exist also about onland outcrops [e.g. Geoffroy, 2005].

Taking into account all these data, we consider that the Fourka unit corresponds to the Maliac oceanic crust because of the MORB affinities of the lavas, the oceanic characteristics of its sedimentary cover (radiolarites and clays) and mainly the long period of volcanic activity (at least from late Anisian to Norian).
If this Fourka unit is a remnant of an oceanic lithosphere, the absence of gabbros and ultramafic basement has to be explained. Two hypotheses have been envisaged some years ago [Ferrière, 1985]: i) an origin by detachement from the top of the main ophiolitic units known in Othris area having a reduced or absent pillow-lavas cover (MI and/or Metalleion units); ii) an origin along the border of the Pelagonian crust and its décollement from its ultramafic basement during the thin-skinned obduction over the Pelagonian continental crust (cf fig 7). The New-Caledonia ophiolites may provide Cenozoic analog of the detachment hypothesis. There, it has been suggested that the pillowlavas were separated from their basement by gravity sliding during the obduction [Lagabrielle et al., 2013]. However,

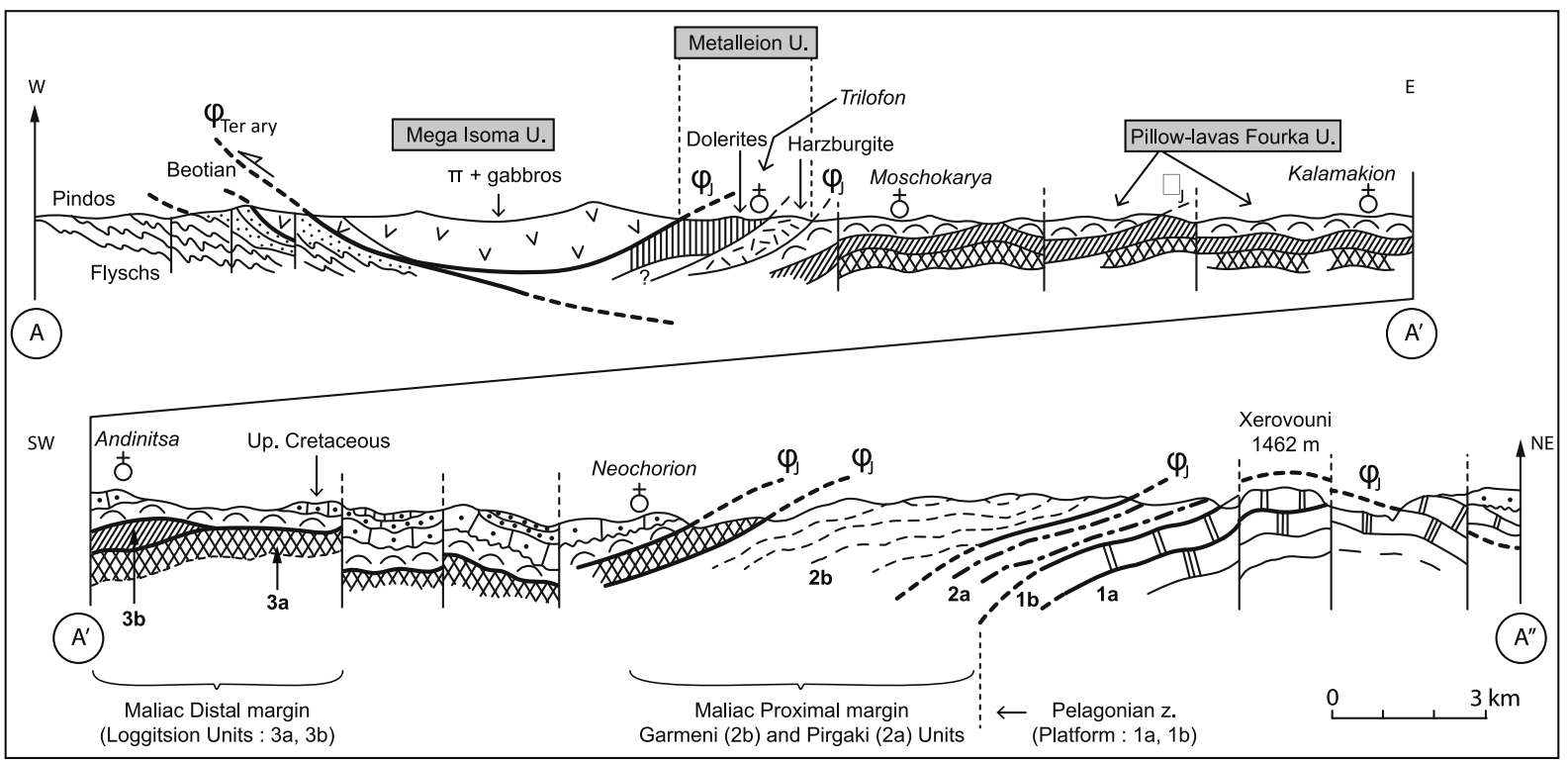

FIg. 3. - Cross-section AA'A” across the Mid-Late Jurassic Maliac syn-obduction ophiolitic and sedimentary nappes above Pelagonian units (Othris mountains). Location on figure 2. 
our new data support the second hypothesis as the Fourka lavas are Triassic in age while the Mega Isoma and Metalleion units are much younger, Middle Jurassic in age. These Jurassic ages are deduced for the Mega Isoma unit from the age of the sediments deposited on the lavas (cf infra, Ekara series) and for the Metalleion unit from a comparison with the similar harzburgitic Vourinos unit, the lavas of which are attributed to the Middle Jurassic [Chiari et al., 2003]. In addition, as the rifting in the Pelagonian platform and Maliac margin is late Anisian-Ladinian in age [Ferrière, 1974, 1982, 1985; Smith et al., 1975], the oceanic lithosphere corresponding to the Middle Triassic Fourka pillow-lavas has to be located at the toe of the PelagonianMaliac margin, and so, it could have easily lost its basement during the obduction on the thick Pelagonian crust.

The age of the earlier MORB generation at the beginning of spreading of the Maliac oceanic lithosphere is relatively close to the age of rifting that has been deduced from paleontological ages of facies changes from platform to deep-sea deposits on the margin [Ferrière, 1982]. Consequently, we assume a relatively rapid episode of rifting on this segment of the Pelagonian margin with a possible diachronism between these two events (rifting then spreading) during this episode (c. 5 to $3 \mathrm{~m} . \mathrm{y}$. duration).

No Liassic sediments have been dated on the Fourka pillow-lavas, even between the Triassic and Middle Jurassic radiolarites of the N-Moschokarya series (fig. 5C). So far, the only Liassic ages from radiolarites related with obducted ophiolitic material came from nodules redeposited in Middle Jurassic sediments present in Argolis peninsula [Chiari et al., 2012b]. A peculiar sedimentary environment unfavourable to radiolarite deposition during this period seems to be a real possibility as the same observation has been made in nearby areas such as the Pindos basin [Fleury, 1980] and the Maliac oceanic margin [Ferrière, 1982].

Our results show that the Fourka lavas eruptions as oceanic sea-floor lasted at least 25-30 m.y., from the Late Anisian (c. $245 \mathrm{Ma}$, in Gradstein et al. [2012]) to the Lower Norian (c. 220-215 Ma). Thanks to its large dimensions and to the long time of oceanic spreading, the Fourka unit has to be considered as a major reference unit for the Triassic evolution of the Maliac oceanic crust. Because of their Triassic age and their MORB and/or WPB affinities, some mafic units or bodies of Greece and Albania have been interpreted as equivalent of the Fourka unit and therefore as old Maliac oceanic lithosphere, even if they are not always proved to be Triassic (radiolarites are often crushed and have tectonic contact with the lavas) or of ophiolitic type (eg. some of them outcrop as blocks of unknown origin in mélanges). Such supposed Triassic ophiolitic lavas have been described in different areas: Argolis (in mélanges, Bortolotti et al. [2001]), northern Evia (a small tectonic sheet, Scherreiks et al. [2010]), Koziakas mountains (small tectonic sheets, Chiari et al. [2012a]), Peloponnessos (associated to an isolated body of gabbros, Danelian et al. [2000]), N-Pindos area (in mélanges, Jones and Robertson [1992]) and from the Mirdita zone of Albania (in a mélange but also in the thin Porava tectonic unit below the main ophiolitic masses, e.g. Bortolotti et al. [2006]). Some other Triassic lavas, supposed to be part of the Fourka unit, belong to the Maliac margin (eg. some lavas described by Bortolotti et al. [2008] and Oszvart et al. [2011]).

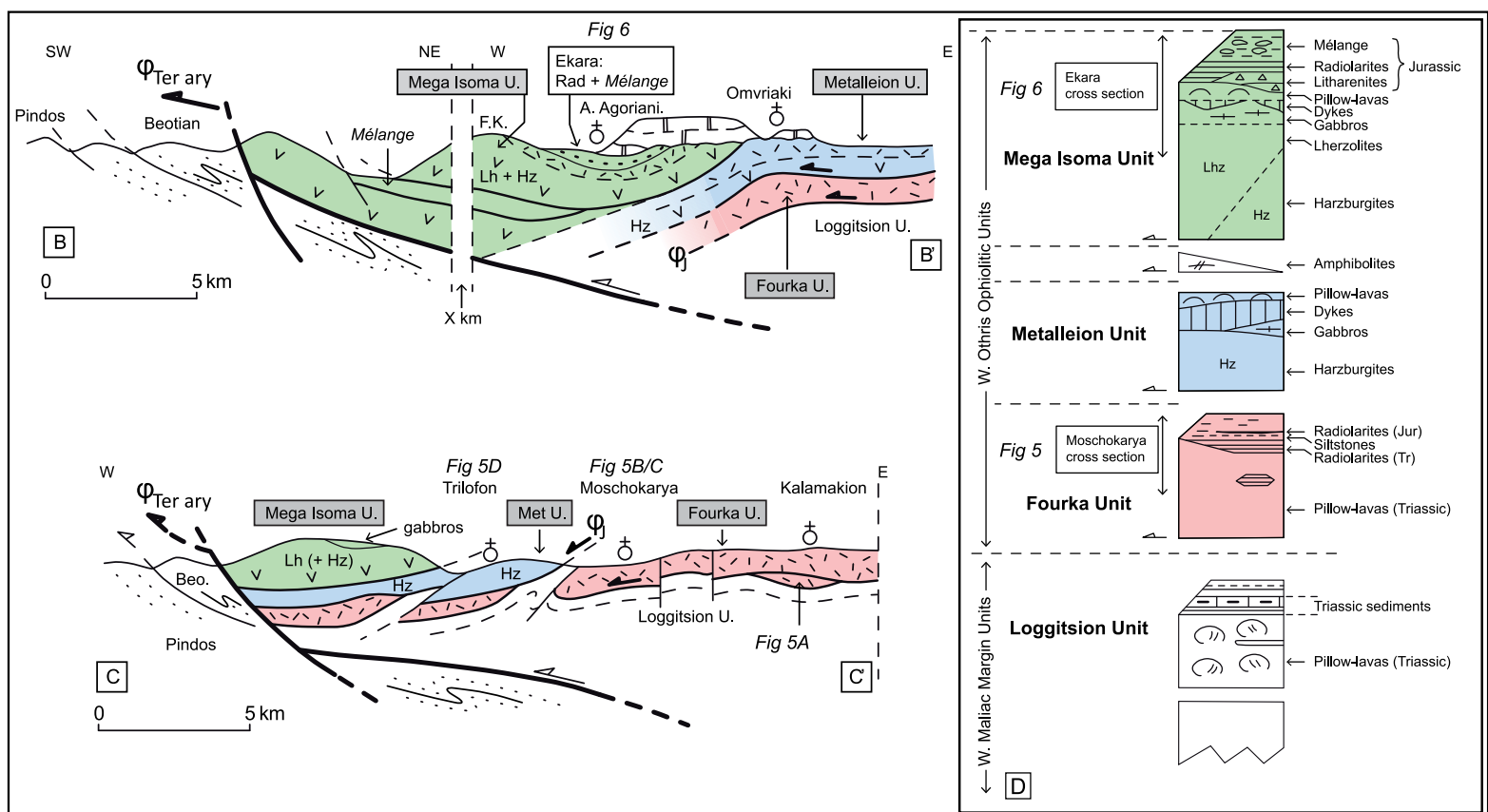

FIG. 4. - Detailed cross-sections across West-Othris Maliac ophiolitic nappes showing the locations of the studied supra-ophiolitic series. Location of BB' and $\mathrm{CC}^{\prime}$ (cf fig. 2).

BB' cross-section: location of the Jurassic Ekara series belonging to the Mega Isoma ophiolitic unit. CC' cross-section: locations of the Kalamakion, Moschokarya and Trilofon areas where crop out the Triassic series on the pillow-lavas of the Fourka unit. Abr. F.K.: Fournos Kaitsa massif; Hz: Harzburgites; Lh : Lherzolites; Met: Metalleion; U: unit (nappe); J: Jurassic .

D: Schematic column summarizing the structural set of syn-obduction nappes in W-Othris with the location of the sedimentary series (Moschokarya and Ekara series) deposited on ophiolitic units. 


\section{THE JURASSIC EKARA SERIES ON THE MEGA ISOMA OPHIOLITIC UNIT}

The published data about the upper ophiolitic unit in Othris [Mega Isoma unit, Celet et al., 1980] concern the peridotites (lherzolites and harzburgites) and their distribution [Menzies and Allen, 1974; Celet et al., 1980; Ferrière, 1982; Dijkstra et al., 2001; Photiades et al., 2003; Barth et al., 2003, 2008]. Sediments supposed to be deposited above the ophiolites have been mentioned by Celet et al. [1980] and
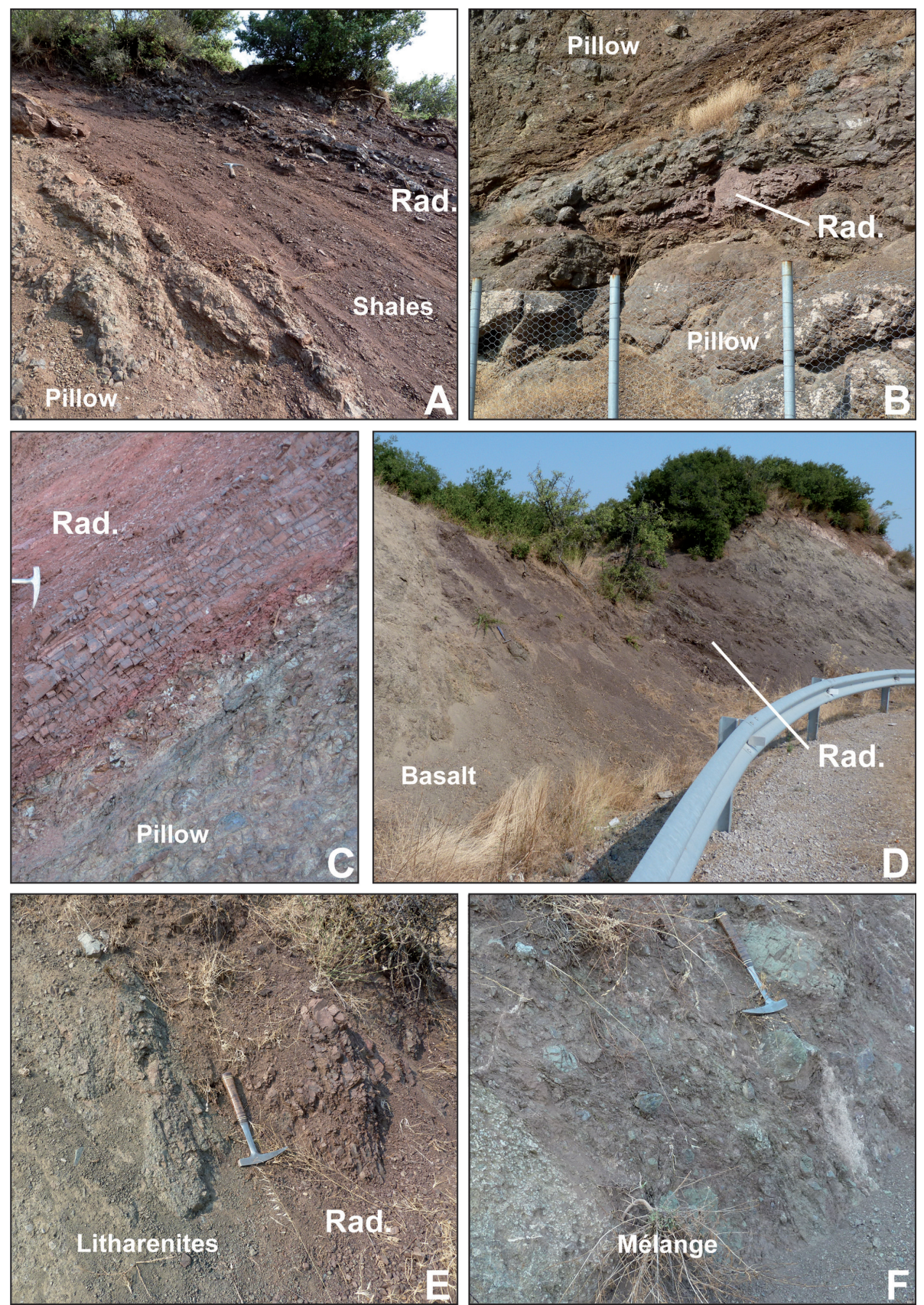

Plate I (outcrops)

A: Late Anisian-?early Ladinian shales and radiolarites on Fourka pillow-lavas (diagram fig. 5A). Road Kalamakion-Fourka pass. Scale: cf hammer. GPS: $38^{\circ} 59,803 \mathrm{~N} ; 22^{\circ} 21,607 \mathrm{E}$

B: Early Norian radiolarites within Fourka lavas (diagram fig. 5B). East of Moschokarya, on the road to Stirfaka. Length of radiolarites outcrop: c. 2,5 m. GPS: $38^{\circ} 59,751 \mathrm{~N} ; 22^{\circ} 16,528 \mathrm{E}$.

C: Clear stratigraphic contact of red Triassic radiolarites on the grey Fourka pillow-lavas (see fig. 5C). North of Moschokarya, on the road to Xinias plain. GPS: $39^{\circ} 0,515 \mathrm{~N} ; 22^{\circ} 15,741 \mathrm{E}$.

D: Contact between Middle Jurassic shaly radiolarites and weathered ophiolitic lavas. This outcrop shows that the radiolarites (Rad) doesn't belong to a tectonic unit located below the Mega Isoma magmatic ophiolitic unit, but are deposited on the crust of this latter unit (cf fig. 6A). Southern outcrop of the Ekara series near Ano Agoriani, on the road to Ekara. GPS: $39^{\circ} 7,751 \mathrm{~N} ; 22^{\circ} 11,779 \mathrm{E}$.

E: The basal formations of the Ekara series near Ekara village (cf fig. 6B). On this outcrop we can see the two main infra-mélange formations: the Middle Jurassic red radiolarites on the basal grey-green litharenites. Northern part of the road between Ano Agoriani and Ekara. GPS: $39^{\circ} 8,950$ N; $22^{\circ} 11,321$ E.

F: The upper part of the Middle Jurassic Ekara series. This melange ("Ekara Melange") is linked to the erosion of intra-oceanic syn-obduction ophiolitic units (cf figs 6B and 7). Along the road Ano Agoriani to Ekara, near Ekara village. GPS: $39^{\circ} 9,035$ N; $22^{\circ} 11,387$ E. 
Ferrière [1982] in the Agoriani-Ekara area near Domokos, but the observed contacts were faulted contacts. More recently, Photiades et al. [2003] and Bortolotti et al. [2008] have published some details on these series but these authors considered that they belong to a separate unit ("Agoriani mélange") located below the ophiolitic MI unit. They give also a Middle Jurassic age (Bathonian-Callovian, UAZ 6 and UAZ 6-7, Baumgartner et al. [1995b]) to this Agoriani Melange thanks to two radiolaritic samples removed from the Ano Agoriani or Ekara (?) area [Bortolotti et al., 2008].

Thank to well exposed outcrops along the new road between Ano Agoriani and Ekara (formerly named Kato Agoriani) the Ekara series appears to be a supra-ophiolitic series with a primary contact on their magmatic basement (figs 4 and 6). The upper part of this series is a chaotic mélange formation but its basal part shows thick non-chaotic strata. To avoid confusion with the term "Agoriani mélange " used by Bortolotti et al. [2008] for this series, we name it "Ekara series". The "mélange" formation that constitutes the upper part of this Ekara series is designed as "Ekara mélange".

\section{The basal radiolarites deposited on the Mega Isoma ophiolites (southern Ekara area)}

The upper part of the peridotite-rich ophiolitic unit of this area is composed of c. 10-20 m of gabbros and highly weathered dolerites-lavas that are covered by siliceous sedimentary rocks. The contact between the lavas and their sedimentary cover is well exposed, mildly deformed but of stratigraphic nature (fig. 6A, pl. ID). The lowest sedimentary levels are shaly thin-bedded radiolarites with few arenitic cm-thick beds. Just above shaly beds (about $10 \mathrm{~m}$-thick) red radiolaritic sediments constitute the upper part of this outcrop (South Ekara log, fig. 6A).

Radiolaria obtained from these red cherts are attributed to the Middle Jurassic (pl. II). Sample AG 01, collected at the base of the sedimentary sequence, yielded a radiolarian fauna including (pl. II): Ristola altissima major BAUMGARTNER \& DE WEVER, Cinguloturris carpatica DUMITRICA, Transhsuum brevicostatum (OzVOLDOVA) and Hexasaturnalis nakasekoi DUMITRICA \& DUMITRICA-JUD. The co-occurrence of these age diagnostic species allows to assign the sample to the unitary association zone 7 (UAZ 7) of Baumgartner et al. [1995b], correlated with the late Bathonian-early Callovian interval. From the upper part of the sedimentary sequence, sample AG 03 yielded an assemblage of a similar age, which can be assigned to UAZ 7 based on the co-occurrence of species Archaeohagiastrum munitum BAUMGARTNER, Dictyomitrella (?) kamoensis MIZUTANI \& KIDO, Eucyrtidiellum ptyctum (RIEDEL \& SANFILIPPO), Eucyrtidiellum unumaense pustulatum BAUMgARTNER, Guexella nudata (Kocher), Stichocapsa robusta MATSUOKA, Williriedellum carpathicum DUMITRICA and Praewilliriedellum robustum MATSUOKA.

\section{The different Jurassic formations of the Ekara series (Ekara village area)}

Nearby Ekara village, some very good outcrops show a complete supra-ophiolitic succession but the basal contact on the ophiolites is unfortunately not well exposed (North Ekara log, fig. 6B). From the bottom to the upper part of the sedimentary pile, we observed the following layers (fig. 6B and pl. IE and F): i) green litharenic levels containing ophiolitic grains or pebbles and some quartz grains with more shaly radiolaritic beds toward its top; ii) red radiolaritic levels (c. $15 \mathrm{~m}$ total thickness) with a meter-thick radiolaritic bed in the middle part; iii) a chaotic formation with pluri-decimetric blocks ("Ekara mélange") resting conformably on top of the red radiolarites. The matrix of the mélange is made up of siliceous shales.

Radiolaria from the lower and upper part of the series reveal Middle to Late Jurassic ages (pl. II). The red shaly radiolarites are late Bathonian to early Callovian, age based on the co-occurrence in sample F11-109 (fig. 6B) of Cinguloturris carpatica DUMITRICA, Dictyomitrella (?) kamoensis MIZUTANI \& KIDO, Eucyrtidiellum ptyctum (RIEDEL \& SANFILIPPO), Loopus primitivus MATSUOKA \& YAO and Guexella nudata (KOCHER) which can be assigned to UAZ 7. Sample F11-111 (fig. 6B, pl. II) can be assigned to UAZ 8 and thus correlated with the middle Callovian-early Oxfordian interval based essentially on the co-occurrence of Eucyrtidiellum unumaense (UAZ 3-8), Podobursa polyacantha (FISCHLI) (UAZ 5-8) and Emiluvia orea orea BAUMGARTNER (UAZ 8-11). Other taxa in this sample are Cinguloturris carpatica DUMITRICA and Parvicingula dhimenaensis ssp A sensu Baumgartner et al. [1995a]. Radiolaria extracted from the red shaly matrix of the mélange are not well preserved. They can be assigned to the UAZ 5 to 8 and correlated with the early Bathonian to early Oxfordian interval based essentially on the presence of Guexella nudata identified in sample F11-112 (fig. 6B).

Above the radiolarites, a main change in sedimentation is outlined by the development of the mélange that is considered to be linked to the initiation of the obduction event (pl. IF). The blocks redeposited in the "Ekara mélange" (radiolarites, pelagic limestones, ophiolitic rocks) testify for an oceanic origin. According to Photiades et al. [2003] lava blocks from this mélange show MORB, MORB-IAT and SSZ affinities. There are no blocks of proven continental origin, considering that the few metamorphic blocks could correspond to oceanic meta-sediments formed at the sole of the ophiolitic nappes.

\section{Clay mineral analyses}

Clay mineral analyses were performed on six samples: three samples recovered at the base of the Ekara series (fig. 6A: AG 01, 03 and 04) and 3 samples from the matrix of the "Agoriani mélange" (fig. 6B: F11-101, 103 and 106). Two of the samples from the basal radiolarites are especially enriched in smectite (AG 03: 82\% and AG 04: 91\%), while the third one (AG 01) is characterized by a smectite $(67 \%)$-illite $(30 \%)$ association. The dominance of smectite likely reflects the vicinity of basic lavas and scarcity in illite is consistent with a relative remoteness of the sedimentary oceanic domain from the margins. The presence of zeolites (clinoptilolite) suggests the occurrence of fluid-basalt interactions.

Rather diversified clay mineral associations characterize the mélange: two samples (F11-101 and F11-103) display complex compositions including illite, smectite, chlorite and regular mixed-layers (rectorite-interstratification of mica and smectite- and corrensite) while the last sample (F11-106), being enriched in smectite (85\%) shows a clay content 


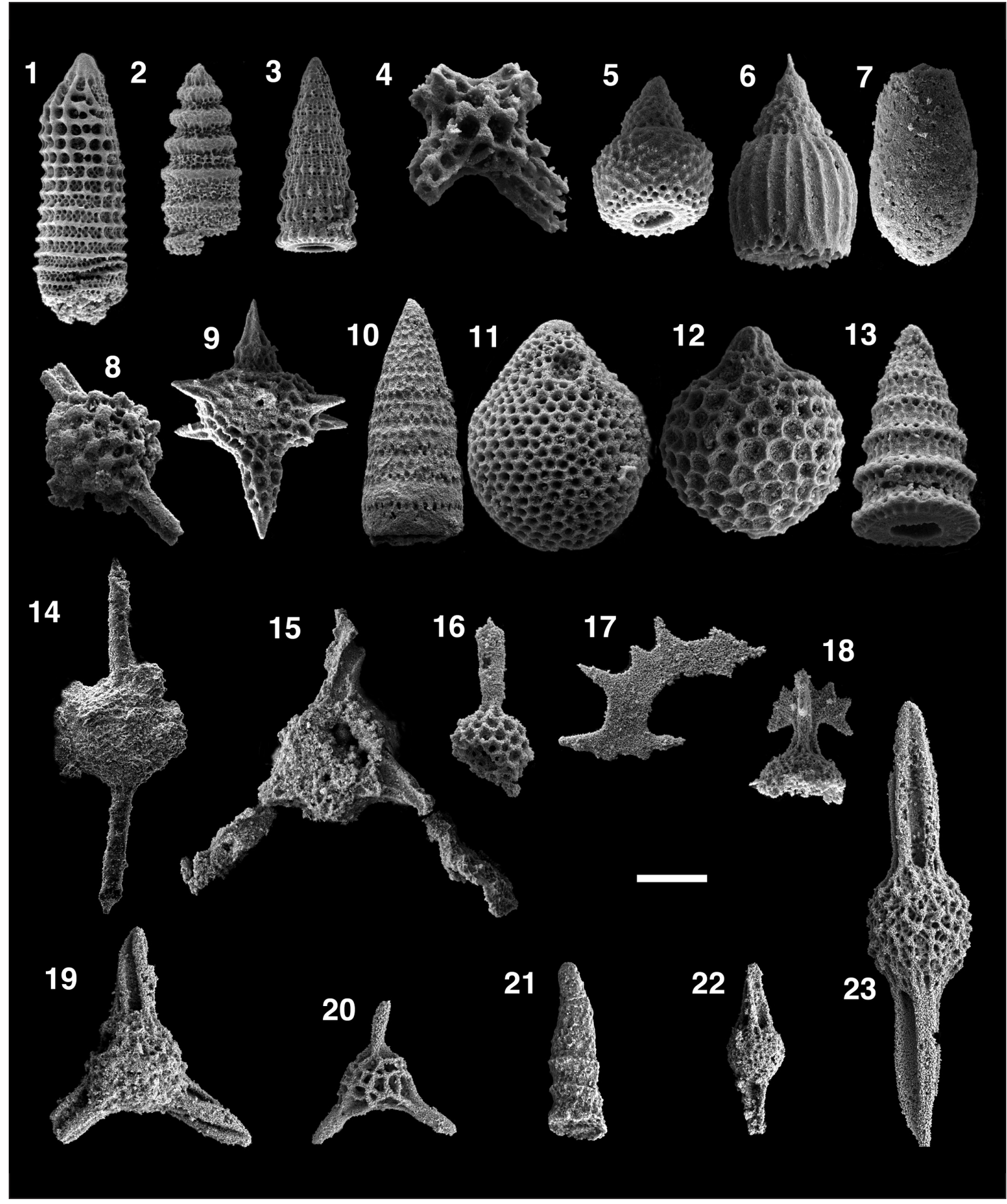

Plate II (Radiolaria)

Middle Triassic to Middle-Late Jurassic radiolarians from the Othris, Scale bar $=100 \mu \mathrm{m}$ for all figures, except for figures 5-7 and 10-13: scale bar $=$ $50 \mu \mathrm{m}$.

1-3: Sample AG 01, UAZ 7, late Bathonian - early Callovian; 1: Ristola altissima major BAUMGARTNER \& De WeVER; 2: Cinguloturris carpatica DumitRICA: 3: Transhsuum brevicostatum (OzVOLDOVA).

4-7 and 11-13: Sample AG 03, UAZ 7, late Bathonian - early Callovian; 4: Archaeohagiastrum munitum BAUMGARTNER, 5: Eucyrtidiellum unumaense pustulatum BAUMGARTNER, 6: Eucyrtidiellum ptyctum (RIEDEL \& SANFILIPPO), 7: Guexella nudata (Kocher), 11: Stichocapsa robusta MATSUOKA, 12: Williriedellum carpathicum Dumitrica, 13: Dictyomitrella (?) kamoensis MizUTANi \& Kido.

8-9: Sample F11-111, UAZ 8, middle Callovian to early Oxfordian; 8: Emiluvia orea orea Baumgartner, 9: Podobursa polyacantha (FISCHLI). 10: Sample F11-109, UAZ 7, late Bathonian - early Callovian, Loopus primitivus MATSUOKA \& YAO.

14-15: Sample FC-02: early Norian; 14: Xiphosphaera? fistulata CARTER; 15: Sarla hadrecaena De Wever.

16-18: Sample F10-AS 8, early Norian; 16: Capnodoce anapetes De WeVer; 17: Palaeosaturnalis triassicus (KozUR \& MostLeR), 18: Kahlerosphaera kemerensis kemerensis TEKIN.

19-20 and 22-23: Sample YO 98, latest Anisian-?earliest Ladinian; 19: Eptingium manfredi Dumitrica, 20: Spongostephanidium spongosium DumitricA, 22: Pseudostylosphaera? sp., 23: Pseudostylosphaera compacta (NAKASEKo \& Nishimura);

21: Sample YO 100, latest Anisian-?earliest Ladinian, Triassocampe scalaris DumitricA, Kozur \& MostLer. 


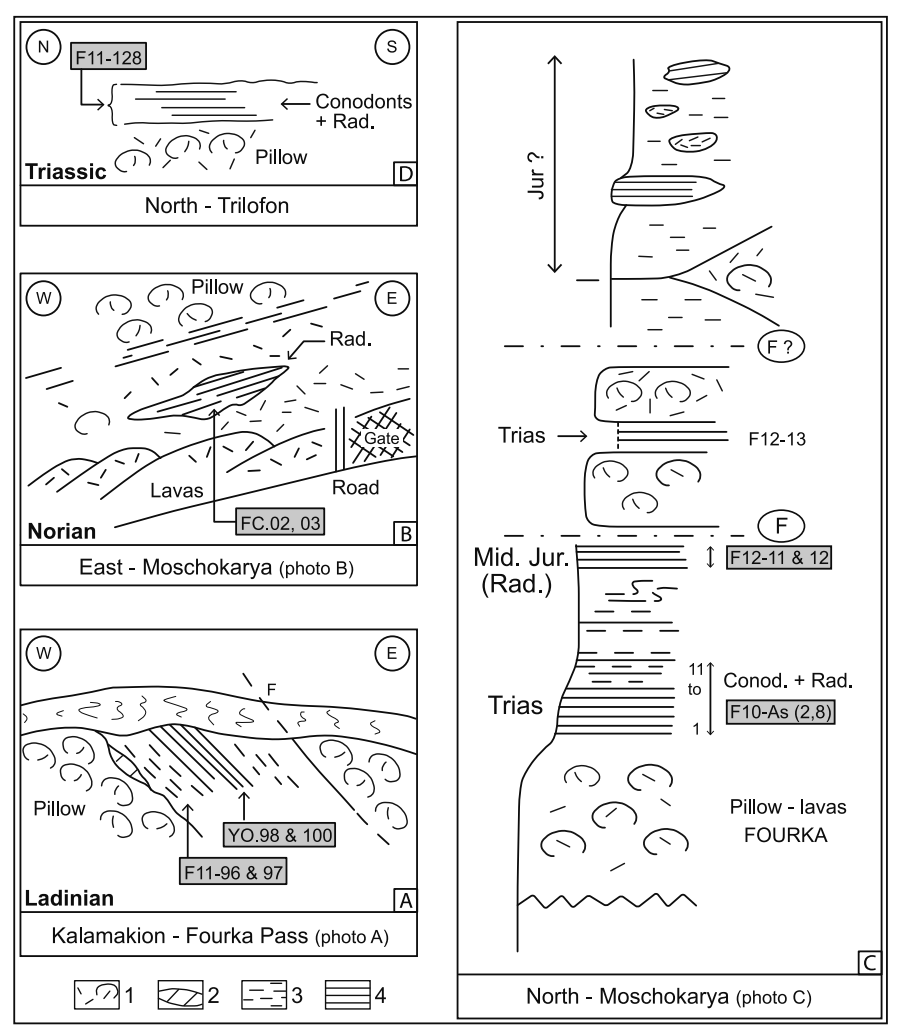

FIG. 5. - (A to D): Sedimentary series associated to the Triassic Fourka pil low-lavas.

1: Pillow-lavas (MORB); 2: calcareous lens above pillow-lavas (fig. 5A); 3: red siliceous shales; 4: red radiolarites. Thicknesses of radiolarites: fig. $5 \mathrm{~A}$ : c. $5 \mathrm{~m}$; fig. $5 \mathrm{~B}$ : c. $1 \mathrm{~m}$; fig. $5 \mathrm{C}$ : c. $10 \mathrm{~m}$ from $\mathrm{F} 10$ As 1 to 11 ; fig. 5D: c. $3 \mathrm{~m}$. For scales see also pl. I.

Abr. Rad: radiolarites; Conod: conodonts; Mid-Jur: Middle-Jurassic; F: normal faults. YO 98 and 100, FC 02-03, F10-As 1 to 11, F11-128 and F12-13: samples with Triassic fossils (Radiolaria and conodonts); F12-11 and 12: samples with Mid-Jurassic fossils (Radiolaria). F11-96, 97 only clay analyses.

similar with $6 \mathrm{~A}$ section basal samples. These observations evidence the influence of reworked materials within the mélange, either components originating from oceanic lithosphere (ophiolitic sheets) or metamorphic rocks (some decimetric blocks exist) likely originated from the sole of the ophiolitic thrust sheets.

\section{The Mid-Jurassic Ekara series: characteristics and interpretation}

Our results relative to the Ekara series show that it is a Jurassic, supra-ophiolitic, complete, diversified succession that, consequently, bring important informations on the corresponding Jurassic Maliac oceanic lithosphere:

- this series covers the uppermost ophiolitic unit (MI unit) of the Jurassic syn-obduction structural set (Pl. ID). The contact between the lavas and overlying sediments is locally a clear stratigraphical contact, which has not been significantly modified by tectonic deformation. Thank to this result it is possible to give a Middle Jurassic age to the MI ophiolite unit, the age of which was unknown;

- the Ekara series, also refered to the "Agoriani Mélange" [Bortolotti et al., 2008] is not only a mélange. It shows thick well-organized sediments (litharenites and radiolarites (pl. IE) deposited before the blocky formation corresponding to the typical syn-obduction "mélange" (pl. IF);

- all the results based upon radiolarian analyses yield Middle (Late?) Jurassic ages, especially late Bathonianearly Callovian (UAZ 7), possibly also locally UAZ 6 according to Bortolotti et al. [2008]. They reach a middle Callovian-early Oxfordian age (UAZ 8) at the top. While Triassic ophiolitic units (e.g. Fourka unit), are mainly made up of lavas, all the main ultramafic ophiolitic massives in Greece and Albania are Jurassic in age, notably the followings: the Mighdalitsa sheet (Argolis [Baumgartner, 1985]), the N-Pindos ophiolite (even if the ages, come from radiolarites sampled in the Avdella mélange [Jones and Robertson, 1992] or the Vourinos massif [Chiari et al., 2003] in Greece; the eastern and western belts of the Mirdita ophiolite in Albania [e.g. Marcucci et al., 1994 in Bortolotti et al., 2004];

- such Middle Jurassic ages show that these deposits are more or less contemporaneous with the beginning of the convergence context (subduction and obduction) based on the ages of SSZ ophiolitic lavas (e.g. from late Bajocian in the Vourinos massif [Chiari et al., 2003]), and of amphibolites of the ophiolitic soles [e.g. Spray et al., 1984; Vergely

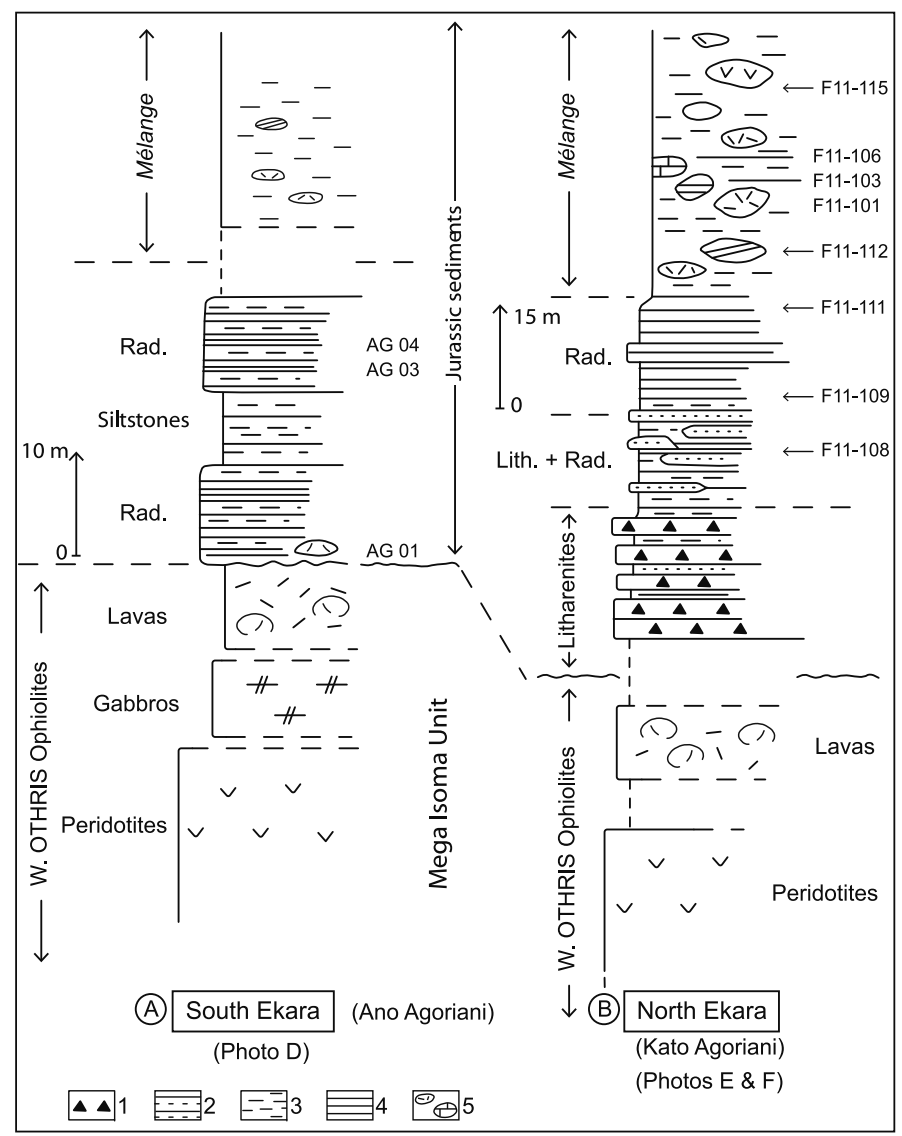

FIG. 6. - Jurassic Ekara series belonging to the Mega Isoma ophiolitic unit (Fournos Kaitsa massif). Abr. Rad: radiolarites; Lith: litharenites. 1: coarsed litharenites with ophiolitic content; 2: sandstones with ophiolitic elements; 3: red siltstones (shales); 4: radiolaritic red beds; 5: chaotic formation ("mélange") with ophiolitic and pelagic sedimentary blocks. AG 01, and 03; F11-109: samples with Mid-Jurassic Radiolaria (UAZ 7); F11-111: sample with Mid to Late Jurassic Radiolaria (UAZ 8). AG 01, 03, 04 and F11-101, 103, 106: clay analyses. 
et al., 1998]. Because it is the uppermost unit of the syn-obduction tectonic system, the MI unit and its cover, the Ekara series, were certainly located in the supra-subduction plate during the obduction events (fig. 7).

Barth et al. [2008] considered that the peridotites of the Fournos Kaitsa massif, which is the part of the MI unit covered by the Ekara series, are similar to abyssal peridotites while some other ultramafic massives of the W-Othris ophiolites (the Metalleion unit and parts of the MI unit) are of SSZ type. This result leads to consider several hypotheses concerning the origin of the basement of the Ekara series (UAZ 7 in age); it could be generated: i) at a mid-oceanic ridge and could have become part of the upper plate at the beginning of subduction (A hypothesis: hyp A, fig. 7), or ii) within the back-arc basin, just after the formation of the Metalleion oceanic basement (UAZ 5 in age from its supposed equivalent, the Vourinos ophiolite). The UAZ 7 age of the MI unit is better explained by this latter hypothesis (hyp B, fig. 7), but to precise the location of the MI unit it is necessary to better know the geochemical affinities of the MI and Metalleion units and the ages of the latter one.

The deposition of the "Ekara Mélange", at the top of the Ekara series, which covers the uppermost ophiolitic unit (MI unit), questions on the source of such detrital material. This source could be: i) an uplifted part of the MI unit supplying blocks to the lower parts of the unit (fig. 7-4); ii) another nappe thrust above the MI one, but now totally eroded; iii) or even the Metalleion unit firstly thrust over the MI nappe (and thus partly eroded), and then overthrust toward the east by this MI unit (fig. 7-4).

\section{CONCLUSIONS}

The structural stack of syn-obduction thrust sheets of Othris mountains is unique, probably the most complete of the Hellenic and Dinaric ranges. Our new ages and structural data from the oceanic series on top of the ophiolitic units allow us to significantly decipher their geometry and evolution. Some of the major ophiolitic units of Othris can therefore be considered as a reference for the Mesozoic seafloor obducted over large areas of Greece and Albania.

\section{The initial Triassic Maliac oceanic crust}

The Fourka unit is a major unrooted thrust sheet constituted of 300 to 400 m-thick pillow-lavas, tectonically separated from their original oceanic basement. Despite the absence of gabbro and peridotite lithologies at its base, this thick pile of lavas, of MORB-type [Hynes, 1974; Ferrière, 1982; Bortolotti et al., 2008; Barth et al., 2009], covered by sediments showing oceanic characters (e.g. radiolarites and siliceous clayey siltstones) and outcropping between the main peridotitic nappes and the lower Maliac margin thrust sheets, has to be considered as part of the former oceanic Maliac lithosphere.

Previous sedimentological characterization [Ferrière, 1982] and few dating of lavas in Othris [Bortolotti et al., 2008], suggested that Maliac oceanic crust existed as early as the Triassic times. As several Triassic ages, and no Jurassic ages, have been obtained from all the radiolarites sampled directly on top of the lavas, or in between the pillows, we consider this oceanic Fourka unit as restricted to
Triassic age. Moreover, because of its large dimensions (thickness and outcrop surface in Othris) linked to a long period of oceanic spreading (c. 25-30 m.y. in duration, between late Anisian-early Ladinian to Norian p.p.), the Fourka unit has to be regarded as the main ophiolitic thrust sheet of the Hellenides exposing the early crust of the Maliac ocean, Triassic in age.

Other Triassic mafic lavas have been described in Greece and Albania. Despite occasionnal uncertainties on their age and/or their ophiolitic nature, some of these Triassic lavas belong probably to the earlier crust of the Maliac ocean e.g. lavas from Argolis, Evia or Koziakas (see text for more details). Regarding the Fourka unit as a whole, rather similar unit can be observed farther north, up to Albania: the Porava unit above the Rubik complex (mélange) [Bortolotti et al., 2006].

According to our new age data, the formation of the basaltic oceanic crust is close to the late Anisian-Ladinian rifting episode known on the Maliac oceanic margin. We therefore conclude that the Fourka unit was created during the earlier stages of oceanic spreading in the vicinity of the rifted Pelagonian continental margin. The location of this oceanic crust at the foot of the Pelagonian margin can account for the subsequent thin-skinned thrusting of the upper part of this proximal oceanic crust during the beginning of obduction (fig. 7-4).

\section{The Middle (to Late?) Jurassic oceanic lithosphere of the Maliac ocean}

Some of the ophiolitic units from Othris are dominated by peridotites. They are among the most important ultramafic units of the Hellenic ophiolitic thrust sheets. One of these large units, the Mega Isoma unit (MI), forms the top of the structural stack obducted during Middle to Late Jurassic times. The geodynamic significance of that unit remained uncertain, largely because its age was not constrained until now. We described in this paper a relatively complete sedimentary cover associated with some of the sparse lava bodies preserved within this unit.

Our new structural data, mapping and dating led to the following results:

- the sedimentary series of Ekara lies without no doubt on the ophiolitic lavas of the Fournos Kaitsa massif, part of the MI ophiolitic unit. The contact between the sediments and the mafic rocks is mildly deformed but not enough to consider it as a tectonic contact. Consequently, the MI ophiolite can be dated as Middle Jurassic in age. While Triassic ophiolitic units are mainly made up of pillow-lavas, the Middle Jurassic ones are the main peridotite-rich ophiolitic units in Greece and Albania (for more details see text);

- observed lavas from the MI unit are too much weathered to produce reliable geochemical results. However, the Middle (and earliest Late Jurassic?) age of the Ekara series, a little younger than the Bajocian-Bathonian lavas of the SSZ Vourinos ophiolites [Chiari et al., 2003], indicates that this oceanic crust (MI unit) was formed during the early stages of convergence (subduction) of the Maliac ocean. As it is the uppermost syn-obduction tectonic unit, the MI unit was probably located in the supra-subduction oceanic plate during the obduction events; 


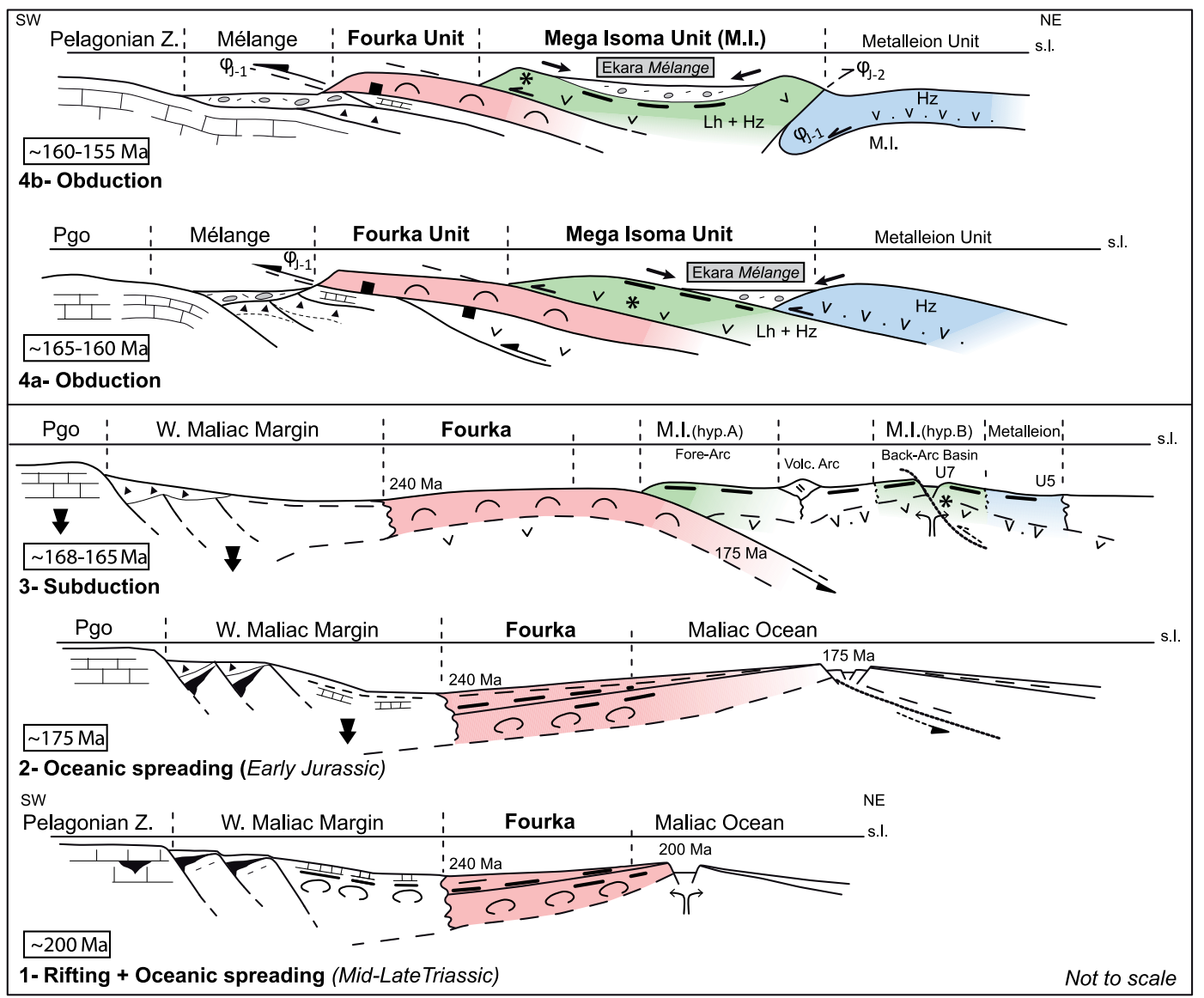

FIG. 7. - Evolution of the Maliac oceanic lithosphere based upon western Othris supra-ophiolitic sedimentary series from Triassic spreading to Mid-Late Jurassic obduction. Abr. Lh: lherzolites; Hz: harzburgites; MI: Mega Isoma unit; Pgo: Pelagonian zone; volc arc: volcanic arc. Black vertical arrows: subsiding areas. Open ellipses: pillow-lavas; black thick dashed lines: studied radiolarites; black thin dashed lines: red siliceous shales; black spots: volcanic rocks in the Pelagonian and proximal Maliac margin (rifting events); bricks: limestones.

1) Triassic oceanic spreading: The new Middle-Late Triassic oceanic crust (c.240 Ma to 200 Ma) corresponds to the Fourka unit.

2) Jurassic oceanic spreading (c.200 to $175 \mathrm{Ma}$ ): At the end of this period (c.175-170 Ma) the divergence and spreading of the Maliac oceanic lithosphere stop and subduction zones appear.

3) Mid-Jurassic subduction (c.168-165 Ma) : the intra-oceanic subduction of the western part of the Maliac oceanic lithosphere initiated at the mid-oceanic ridge (?) gives rise to an intra-oceanic volcanic arc and to a back-arc oceanic lithosphere. This new SSZ lithosphere corresponds to the Metalleion unit (UAZ 5 in age) and probably to the Mega Isoma unit (UAZ 7 in age) (B hypothesis: hyp B). Another possibility (hyp A) is that the MI unit comes from a lithosphere located in the forearc area but the UAZ 7 age of the MI unit is better explained by the first hypothesis (hyp B). This latter one has been prefered and is the only one represented on the figure (cf 4)

4) Mid-Late Jurassic oceanic to continental obduction: The intra-oceanic obduction gives rise to the three main ophiolitic nappes known in the West-Othris area (Mega Isoma, Metalleion and Fourka units). The "mélange" of the Ekara series deposited on the thin mafic crust of the MI unit, comes from the erosion of this unit and/or from another one (4a and $4 \mathrm{~b})$

Just after the intra-oceanic obduction (4a), the oceanic lithosphere is thrust onto the continental crust (obduction s.s.) corresponding to the Maliac oceanic margin and then, onto the Pelagonian zone (4b). The Fourka ophiolitic unit loses its peridotitic basement and a new "chaotic mélange" is deposited in front of the ophiolitic nappes on the proximal Maliac units, then onto the Pelagonian zone (4b).

- the base of the Ekara series is locally constituted of litharenites rich in ophiolitic elements coming from its own basement. However, in other localities, shaly radiolarian beds cover directly the ophiolitic mafic rocks. These radiolarites testify for a, more or less, quiet period of sedimentation despite the convergence context;

- the upper part of the Ekara series is a sedimentary mélange formation bearing blocks of ophiolitic material (i.e. serpentinite, basalt, gabbro, radiolarite) in a siliceous shaly matrix. According to its composition, this mélange has to be considered as a syn-obduction formation. Consequently, it appears that the MI unit formed part of the Maliac oceanic lithosphere up to the beginning of the intra- oceanic obduction (fig. 7-4). The presence of ophiolitic blocks in a mélange formation on top of the uppermost MI unit testifies for a source from an uplifted part of this unit or of another oceanic unit on top of it (fig. 7-4). The continuity in the Ekara series between the radiolarites and the mélange permits to conclude that the intra-oceanic obduction was active since at least the late Callovian-earliest Oxfordian times (UAZ 8).

The new data exposed in this paper permit to significantly constrain the structural stacking and the evolution of ophiolitic bodies in the Othris mountains. Similar ophiolitic bodies are exposed all over the internal Hellenides of Greece and Albania. The geometry and structural evolution 
deduced from the ophiolitic thrust sheets of Othris can be applied to this whole domain involved in the Jurassic obduction of the former Middle Triassic to Middle Jurassic Maliac ocean.

Acknowledgements. - The authors thank Y. Lagabrielle and S. Gorićan for their reviews which allowed to greatly improve the manuscript.
We also thank: Olivier Averbuch and Pitaksit Ditbanjong, for their participation in field work in Othris mountains; Yannick Gingins and Olivier Schauner, for their earlier work on collecting and processing radiolaria data. Moreover, we would like to greatly acknowledge Marion Delattre, Philippe Recourt and Alexandre Fadel for the technical work concerning the extraction and preparation of microfossils.

SGF associate editor: Pierre-Yves Collin

\section{References}

Barth M.G., Mason P.R.D., Davies G.R., Dijkstra A.H. \& Drury M.R. (2003). - Geochemistry of the Othris Ophiolite, Greece: Evidence of refertilization? - Journal of Petrology, 44, 1759-1785.

Barth M.G., Mason P.R.D., Davies G.R. \& Drury M.R. (2008). - The Othris Ophiolite, Greece: A snapshot of subduction initiation at a mid-ocean ridge. - Lithos, 100, 234-254.

Barth M.G., Tatjana A.E. \& GluhaK M. (2009). - Geochemistry and tectonic setting of mafic rocks from the Othris Ophiolite, Greece. Contributions to Mineralogy and Petrology, 157, 23-40.

BAUMGARTNER P.O. (1985). - Jurassic sedimentary evolution and nappe emplacement in the Argolis peninsula (Peloponnesus, Greece).Denkschriften der Schweizerischen Naturforschenden Gesellschaft, 99, $111 \mathrm{pp}$.

Baumgartner P.O., O'Dogherty L., Gorićan S., Dumitrica-Jud R. Dumitrica P., Pillevuit A., Urquhart E., Matsuoka A., Danelian T., Bartolini A., Carter E.S., De Wever P., Kito N., Marcucci M., \& Steiger T.A. (1995a). - Radiolarian catalogue and systematics of Middle Jurassic to Early Cretaceous Tethyan genera and species. In: P.O. BAumgartner, L. O'Dogherty, S Gorićan, E. Urquhart, A. Pillevuit and P. De Wever, Eds, Middle Jurassic to Lower Cretaceous Radiolaria of Tethys: oc currences, systematics, biochronology. - Mémoires de Géologie (Lausanne) 23, 37-685.

Baumgartner P.O., Bartolini A., Carter E.S., Conti M., Cortese G., Danelian T., De Wever P., Dumitrica P., Dumitrica-Jud R., Gorićan S., Guex J., Hull D.M., Kito N., Marcucci M., MatSuOKa A., Murchey B., O’Dogherty L., SAVAry J., VishnevsKAYA V., WidZ D. \& YAO A. (1995b). - Middle Jurassic to Early Cretaceous radiolarian biochronology of Tethys based on Unitary Associations. In: P.O. Baumgartner, L. O'Dogherty, S. Gorićan, E. Urquhart, A. Pillevuit and P. De Wever, Eds, Middle Jurassic to Lower Cretaceous Radiolaria of Tethys: occurrences, systematics, biochronology. - Mémoires de Géologie (Lausanne) 23, 1013-1048.

Beccaluva L., Ohnenstetter D., Ohnenstetter M. \& Paupy A. (1984). Two magmatic series with island arc affinities within the Vourinos ophiolite. - Contributions to Mineralogy and Petrology, 85, 253-271.

Bernoulli D. \& Laubscher H. (1972). - The palinspatic problem of the Hellenides. - Eclogae geologica Helvetica, 65/1, 107-118.

Bortolotti V., Chiari M., Marcucci M., Photiades A. \& Principi G. (2001). - Triassic radiolarian assemblages from the cherts associated with pillow-lavas in Argolis peninsula (Greece). - Ofioli$t i$, abstract, 26, 75 .

Bortolotti V., Chiari M., Marcucci M., Marroni M., Pandolfi L., PrinCIPI G. \& SACCANI E. (2004). - Comparison among the Albanian and Greek ophiolites: in search of constraints for the evolution of the Mesozoic Tethys ocean. - Ofioliti, 29, 19-35.

Bortolotti V., Chiari M., Kodra A., Marcucci M., Marroni M., Mustafa F., Prela M., Pandolfi L., Principi G. \& Saccani E. (2006). Triassic MORB magmatism in the southern Mirdita zone (Albania). - Ofioliti, 31, 1-9.

Bortolotti V., Chiari M., Marcucci M., Photiades A., Principi G. \& SACCANi E. (2008). - New geochemical and age data on the ophiolites from the Othrys area (Greece): implication for the Triassic evolution of the Vardar ocean. - Ofioliti, 33, 135-151.
Bortolotti V., Chiari M., Marroni M., Pandolfi L., Principi G. \& Saccani E. (2013). - Geodynamic evolution of ophiolites from Albania and Greece, Dinaric-Hellenic belt: one, two or more oceanic basins? International Journal Earth Sciences, 102, 738-811, doi 10.1007/s00531-012-0835-7.

BRUNN J.H. (1956). - Contribution à l'étude du Pinde septentrional et d'une partie de la Macédoine occidentale. - Annales Géologique des Pays Helleniques, 7, 1-358.

Capedri S., Venturelli G., Bebien J. \& Toscani L. (1981). - Low- and high-Ti ophiolites in northern Pindos: petrological and geological constraints. - Bulletin of Volcanology, 44, 439-449.

Celet P., Courtin B. \& Ferrière J. (1980). - Les ophiolites des Hellenides centrales dans leur contexte géotectonique. - Ophiolites, Proceedings International Ophiolite Symposium Cyprus, 360-371.

Chiari M., Bortolotti V., Marcucci M., Principi G. \& Photiades A. (2003). - The Middle Jurassic siliceous sedimentary cover at the top of the Vourinos Ophiolite (Greece). - Ofioliti, 28, 95-103.

Chiari M., Bortolotti V., Marccuci M., Photiades A., Principi G. \& SACCANI E. (2012a). - Radiolarian biostratigraphy and geochemistry of the Koziakas massif ophiolites (Greece). - Bulletin de la Société géologique de France, 183, 287-306.

Chiari M., Baumgartner P.O., Bernoulli D., Bortolotti V., Marcucc M., Photiades A. \& Principi G. (2012b). - Late Triassic, Early and Middle Jurassic Radiolaria from ferromanganese-chert 'nodules' (Angelokastron, Argolis, Greece): evidence for prolonged radiolarite sedimentation in the Maliac-Vardar ocean. - Facies, doi: $10.1007 /$ s10347-012-0314-4.

Danelian T. \& Robertson A. (2001) - Neotethyan evolution of eastern Greece (Pagondas Mélange, Evvoia island) inferred from radiolarian biostratigraphy and the geochemistry of associated extrusive rocks. - Geological Magazine, 138, 345-363.

Danelian T., LekKas S. \& Alexopoulos A. (2000). - Découverte de radiolarites triasiques dans un complexe ophiolitique à l'ExtrêmeSud du Péloponnèse (Agelona, Lakonie, Grèce). - Comptes Rendus de l'Académie des Sciences, Paris, 330, 639-644.

Dercourt J. (1970). - L'expansion océanique actuelle et fossile: ses implications géotectoniques. - Bulletin de la Société géologique de France, XII (7), 261-317.

DiJKstra A., DruRy M.R. \& Vissers R.L.M. (2001). - Structural petrology of plagioclase peridotites in the West Othris mountains (Greece): Melt impregnation in mantle lithosphere. - Journal of Petrology, 42, 5-24.

FERRIÈre J. (1972). - Sur l'importance des déplacements tangentiels en Othrys centrale au NE d'Anavra (Grèce). - Comptes Rendus de l'Académie des Sciences, Paris, 274, 174-176.

FERRIÈrE J. (1974). - Etude géologique d'un secteur des zones helleniques internes sub-pé lagoniennes (massif de l'Othrys, Grèce orientale). Importance et signification de la période orogénique antéCretacé supérieur. - Bulletin de la Société géologique de France, XVI (5), 543-562.

FERRIÈre J. (1976). - Sur la signification des séries du massif de l'Othrys (Grèce continentale): la zone isopique Maliaque. - Annales de la Société géologique du Nord, 96, 121-134.

FERrière J. (1982). - Paléogéographies et tectoniques superposées dans les Hellenides internes au niveau de l'Othris et du Pelion (Grèce). Société Géologique du Nord, Publication 8, 970 pp.

FERRIÈre J. (1985). - Nature et développement des ophiolites helleniques du secteur Othrys-Pelion. - Ofioliti, 10, 255-278. 
Ferrière J., Bertrand J., Simantov J. \& De Wever P. (1988). - Comparaison entre les formations volcano-détritiques ("Mélanges") du Malm des Hellenides internes (Othrys, Eubée). - Bulletin of the Geological Society of Greece, XX, 223-235.

Ferrière J., Chanier F. \& Ditbanjong P. (2012). - The Hellenic ophiolites: eastward or westward obduction of the Maliac ocean, a discussion. - International Journal of Earth sciences, 101, 1559-1580.

Fleury J.-J. (1980). - Les zones de Gavrovo-Tripolitza et du Pinde-Olonos (Grèce continentale) et Péloponnèse du Nord. Evolution d'une plate-forme et d'un bassin dans leur cadre Alpin. - Société Geologique du Nord, Publication 4, 1651 pp.

Geoffroy L. (2005). - Volcanic passive margins. - Comptes Rendus Geoscience, 337, 1395-1408.

Gradstein F.M., Ogg J.G., Schmitz M.D. \& OgG G.M. (2012). - The geologic time scale 2012. - Elsevier, Oxford, U.K.

HYNES A. (1974). - Igneous activity at the birth of an ocean basin in eastern Greece. - Canadian Journal of Earth Sciences, 11, 842-853.

Hynes A., Nisbet E.G., Smith A.G., Welland M.J.P. \& Rex D.C. (1972) - Spreading and emplacement ages of some ophiolites in the Othris region (eastern central Greece). - Zeitschrift der Deutschen Geologischen Gesellschaft., 123, 455-468.

JoNes G. \& RoBERTSON A.H.F. (1991). - Tectono-stratigraphy and evolution of the Mesozoic Pindos Ophiolite and related units, northwestern Greece: an integrated supra-subduction zone spreading and subduction-accretion model. - Jounal of the Geological Society, London, 148, 267-288.

Jones G. \& Robertson A.H.F. (1994). - Rift-drift-subduction and emplacement history of the early Mesozoic Pindos ocean: Evidence from the Avdella Mélange, northern Greece. - Proceedings of the 7th Congress, Thessaloniki. - Bulletin of the Geological Society of Greece, 30, 45-58.

Jones G., De WeVer P. \& Robertson A.H.F. (1992). - Significance of radiolarian age data to the Mesozoic tectonic and sedimentary evolution of the northern Pindos mountains, Greece. - Geological Magazine, 129, 385-400.

Lagabrielle Y., Chauvet A., Ulrich M. \& Guillot S. (2013). - Passive obduction and gravity-driven emplacement of large ophiolitic sheets: The New Caledonia ophiolite (SW Pacific) as a case study? - Bulletin de la Société géologique de France, 184, 545-556.

MenZies M. \& Allen C. (1974). - Plagioclase lherzolite-residual mantle. Relationships within two eastern Mediterranean ophiolites. Contributions to Mineralogy and Petrology, 45, 197-213.

Ozsvart P., Dosztaly L., Migiros G., Tselepidis V. \& Kovacs S. (2011). New radiolarian biostratigraphic age constraints on Middle Triassic basalts and radiolarites from the Inner Hellenides (northern Pindos and Othris mountains, northern Greece) and their implications for the geodynamic evolution of the early Mesozoic Neotethys. - International Journal of Earth Sciences, doi: $10.1007 / \mathrm{s} 00531-010-0628-9$.

Photiades A., Saccani E. \& TAssinari R. (2003). - Petrogenesis and tectonic setting of volcanic rocks from the Subpelagonian ophiolitic melange in the Agoriani area (Othris, Greece). - Ofioliti, 28 121-135.

Rassios A.H.E. \& Moores E.M. (2006). - Heterogeneous mantle complex, crustal processes and obduction kinematics in a unified PindosVourinos ophiolitic slab (northern Greece). In: A.H.F. ROBERTSON and D. MounTRAKIs, Eds, Tectonic development of the eastern Mediterranean region. - Geological Society London, Special Publication, 260, 237-266.

Robertson A.H.F. (2012). - Late Palaeozoic-Cenozoic tectonic development of Greece and Albania in the context of alternative reconstructions of Tethys in the eastern Mediterranean region. International Geology Review, 54, 373-454.
Robertson A.H.F., Clift P.D., Degnan P.J. \& Jones G. (1991). - Paleogeographical and paleotectonic evolution of the eastern Mediterranean Neotethys. - Paleooceanography, Paleoclimatology, Paleoecology, 87, 289-343.

Ross R. \& Zimmermann J. (1996). - Comparaison of evolution and tectonic significance of the Pindos and Vourinos ophiolite suites, northern Greece. - Tectonophysics, 256, 1-15.

Saccani E. \& Photiades A. (2004). - Mid-ocean ridge and supra-subduction affinities in the Pindos ophiolites (Greece): implications for magma genesis in a forearc setting. - Lithos, 73, 229-253.

Saccani E., Padoa E. \& Photiades A. (2003). - Triassic mid-ocean ridge basalts from the Argolis peninsula (Greece): New constraints for the early oceanization phases of the Neo-Tethyan Pindos basin. In: Y. DileK and P.T. RoBINSON, Eds, Ophiolites in earth history. Geological Society of London, Special Publication, 218, 109-127.

Saccani E., Beccaluva L., Coltorti M. \& Siena F. (2004). - Petrogenesis and tectono-magmatic significance of the Albanide-Hellenide subpelagonian ophiolites. - Ofioliti, 29, 75-93.

Saccani E., Beccaluva L., Photiades A. \& Zeda O. (2011). - Petrogenesis and tectono-magmatic significance of basalts and mantle peridotites from the Albanian-Greek ophiolites and sub-ophiolitic mélanges. New constraints for the Triassic-Jurassic evolution of the Neo-Tethys in the Dinaride sector. - Lithos, 124, 227-242.

Scherreiks R., Bosence D., Boudagher-Fadel M., Melendez G. \& Baumgartner P.O. (2010). - Evolution of the Pelagonian carbonate platform complex and the adjacent oceanic realm in response to plate tectonic forcing (Late Triassic and Jurassic), Evvoia, Greece. - International Journal of Earth Sciences, 99, 1317-1334.

Schmid M.S., Bernoulli D., Fügenschun B., Matenco L., Schefer S., Schuster R., Tischler M. \& Ustaszewski K. (2008). - The Alpine-Carpathian-Dinaridic orogenic system: correlation and evolution of tectonic units. - Swiss Journal of Geosciences, 101, 139-183.

Smith A.G., Hynes A.J., Menzies M., Nisbet E.G., Price I., Welland M.J. \& FERRIÈre J. (1975). - The stratigraphy of the Othris mountains, eastern Central Greece: a deformed Mesozoic continental margin sequence. - Eclogae Geologica Helvetica, 68, 463-481.

Spray J.G., Bebien J., Rex D.C. \& Roddick J.C. (1984). - Age constraints on the igneous and metamorphic evolution of the Hellenic-Dinaric ophiolites. In: J.E. Dixon and A.H.F. RoberTson, Eds, The geological evolution of the eastern Mediterranean. - Geological Society London Special Publication, 17, 619-627.

Stampfi G.M. \& Borel G. (2002). - A plate tectonic model for the Paleozoic and Mesozoic constrained by dynamic plate boundaries and restored synthetic oceanic isochrones. - Earth Planetary Science Letters, 196, 17-33.

Stockar R., Dumitrica P. \& Baumgartner P.O. (2012). - Early Ladinian radiolarian fauna from the Monte san Giorgio (southern Alps, Switzerland): Systematics, biostratigraphy and paleo(bio)geographic implications. - Rivista Italiana di Paleontologia e Stratigrafia, 118, 373-437.

Vergely P., Dimo A. \& Monie P. (1998). - Datation des semelles métamorphiques ophiolitiques d'Albanie par la méthode ${ }^{40} \mathrm{Ar} /{ }^{39} \mathrm{Ar}$ : Conséquences sur le mécanisme de leur mise en place. - Comptes Rendus de l'Académie des Sciences, Paris, 326, 717-722.

Zimmerman J. (1972). - Emplacement of the Vourinos ophiolitic complex, northern Greece. - Geological Society of America Memoir, 132, 225-239. 